\title{
Iron status of children with phenylketonuria undergoing nutrition therapy assessed by transferrin receptors
}

Phyllis B. Acosta, Dr $P H^{1}$, Steven Yannicelli, $P h D^{1}$, Rani H. Singh, $P h D^{2}$, Louis J. Elsas II, $M D^{2}$, Shideh Mofidi, $M S^{3}$, and Robert D. Steiner, $M D^{4}$

\begin{abstract}
Purpose: The purpose of the study was to determine the incidence of iron deficiency in children undergoing therapy for phenylketonuria using serum transferrin receptor and ferritin concentrations. Methods: A 1-year study was conducted in 37 children $2<13$ years old with phenylketonuria (8 fed Periflex [Group I], 15 fed Phenex-2 Amino Acid-Modified Medical Food [Group II], and 14 fed Phenyl-Free [Group III]). Hemoglobin, hematocrit, serum transferrin receptor, and ferritin concentrations were assessed at baseline and 12 months and intakes of protein, iron, and vitamin C were evaluated at baseline and at 3-month intervals. Transferrin receptor and ferritin concentrations were analyzed for group differences by analysis of variance. Results: Mean protein, iron, and vitamin C intakes of all 3 groups of children were greater than Recommended Dietary Intakes for age. Only 2 of 60 3-day diet diaries of Group II children failed to contain $100 \%$ of Recommended Dietary Intakes for iron during study. The following number of children had iron status indices outside reference ranges at study end: 7 children, transferrin receptor/ferritin ratios; 4 children, transferrin receptors; 2 children, hematocrit; 1 child, ferritin. No correlation was found between iron intake and any index of iron status. Conclusions: The transferrin receptor/ ferritin ratio appeared to be the most sensitive index of iron deficiency in this study. Reasons for iron deficiency with greater than recommended iron intakes by children with phenylketonuria may be multiple. Early assessment and therapy of iron deficiency may improve cognitive and behavioral outcomes of children with PKU. Genet Med
\end{abstract} 2004:6(2):96-101.

Key Words: phenylketonuria, iron status indices, ferritin, transferrin receptors

Phenylketonuria (PKU) (McKusick 26160) is an inherited disorder of phenylalanine (Phe) metabolism characterized by the inability to normally change Phe to tyrosine (Tyr) due to mutation(s) in the phenylalanine hydroxylase (PAH) gene (EC1.14.16.1). Without diet restriction of Phe to maintain plasma Phe concentration between 120 and $360 \mu \mathrm{mol} / \mathrm{L}$, severe mental retardation, seizures, skin lesions, and neurological symptoms occur in affected persons. ${ }^{1}$ Diet restriction of Phe requires the use of a Phe-free medical food to supply, on average, $75 \%$ of prescribed protein. ${ }^{2}$ Intact protein from low-protein cereals,

From ${ }^{1}$ Ross Products Division, Abbott Laboratories, Columbus, Ohio; Present address for S.Y. Pharmavite, Northridge, California; ${ }^{2}$ Division of Medical Genetics, Department of Pediatrics, Emory University School of Medicine, Atlanta, Georgia; Present address for L.J.E., John T. MacDonald Foundation Center for Medical Genetics, University of Miami, Miami, Florida; ${ }^{3}$ Children's Hospital, Los Angeles, California; Present address for S.M., Regional Medical Genetic Center, New York Medical College, Westchester, New York; and ${ }^{4}$ Division of Metabolism, Departments of Pediatrics and Molecular and Medical Genetics, Oregon Health and Science University, Portland, Oregon.

Phyllis B. Acosta, Ross Products Division, Abbott Laboratories, Columbus, OH 43215. Attn: Barbara Marriage, $P h D$

Received: October 28, 2003.

Accepted: December 15, 2003.

DOI: 10.1097/01.GIM.0000117335.50541.F3 fruits, and vegetables to supply the Phe requirement provides the remainder of the protein prescription, whereas additional energy needs are satisfied by nitrogen-free foods such as pure sugars and oils. Using serum ferritin concentration as the indicator, a number of investigators ${ }^{2-5}$ have reported iron deficiency in children undergoing therapy for PKU despite iron intakes greater than Recommended Dietary Allowances (RDA). ${ }^{6,7}$ The form of iron in all medical foods used in the United States for children with PKU is ferrous sulfate of which about $3 \%$ to $5 \%$ is normally absorbed. ${ }^{8}$ Iron deficiency in normal infants and children is reported to affect cognitive development ${ }^{9}$ and behavior, ${ }^{10}$ whereas children with PKU are at cognitive and behavioral risk due to their disorder. ${ }^{11}$ The purpose of this study was to determine the incidence of iron deficiency in children undergoing therapy for PKU using serum transferrin receptor (TFR) and ferritin concentrations.

\section{MATERIALS AND METHODS}

\section{Study design}

A 1-year longitudinal study was conducted in children with PKU ages $2<13$ years undergoing therapy with Phe-free medical foods. Nutrient intake was assessed at baseline and every 3 months during study and hemoglobin, hematocrit, ferritin, 
and TFR concentrations were assessed at baseline and study end. This study began in March, 1996, and ended December 1999. Three sites participated in the study.

\section{Ethical considerations}

Investigators obtained approval of the study and consent form from the Institutional Review Board at participating clinics or hospitals. Parents of all children signed informed consent forms.

\section{Subject selection criteria}

Children who met the following criteria were studied: diagnosed with classical PKU and treatment initiated within the first month of life; free of major congenital anomalies and cardiac, liver, neurological, renal, or pulmonary disease; major surgery, trauma, and broken bones did not occur during study; $\geq 2$ but $<12$ years of age and not beyond Tanner development stage $2^{12}$ at study entrance. Parents agreed to follow the nutrition support protocol that required ingestion of a daily minimum total protein from medical food and intact protein of $30 \mathrm{~g}$ by $2<4$ year olds, $35 \mathrm{~g}$ by $4<7$ year olds, 40 g by $7<11$ year olds, $50 \mathrm{~g}$ by females $11<13$ years old, and $55 \mathrm{~g}$ by males $11<13$ years old.

\section{Study feedings}

Periflex, Phenex-2, and Phenyl-free

Selected nutrients provided by labels for medical foods per $100 \mathrm{~g}$ are shown in Table 1. Periflex is manufactured by Scientific Hospital Supplies, Ltd, Liverpool, UK. Phenex-2 Amino Acid-Modified Medical food is manufactured by Ross Products Division, Abbott Laboratories, Columbus, OH. Composition of Phenyl-Free (Mead Johnson Nutritionals, Evansville, IN) changed somewhat during the study with a slight decrease in protein equivalent and energy. Protein equivalent content of these medical foods is based on nitrogen content, i.e., nitrogen (g) $\times 6.25=$ g protein equivalent.

\section{Diet assessment}

Diet assessment was based on 3-day diet diaries obtained at baseline and 3, 6, 9, and 12 months of study. Parents were taught to record diet diaries by the local nutritionist. Amino Acid Analyzer software (Ross Products Division, Abbott Laboratories, Columbus, $\mathrm{OH}$ ) was used to calculate means of 3-day nutrient intakes from medical foods and intact protein-

Table 1

Label claims of medical foods for children with phenylketonuria per $100 \mathrm{~g}$ powder

\begin{tabular}{lcccc}
\hline & & & \multicolumn{2}{c}{ Phenyl-Free } \\
\cline { 4 - 5 } Nutrient & Periflex & Phenex-2 & $\leq 11 / 97$ & $>11 / 97$ \\
\hline Protein equiv, g & 20.0 & 30.0 & 20.0 & 19.8 \\
Iron, mg & 12 & 13 & 12.2 & 11.9 \\
Vitamin C, mg & 45 & 60 & 53 & 52 \\
\hline
\end{tabular}

containing foods. Mean \pm SEM of protein, iron, and vitamin C at baseline and during study were compared to Recommended Dietary Intakes (RDIs) (Table 2), a modification of 1980 and 1989 RDAs. ${ }^{6,7}$ For purposes of this study, RDIs were defined as the greatest values for age in the 1980 and 1989 RDAs. ${ }^{6,7}$ These values were used, rather than RDAs recently proposed by the Institute of Medicine for normal persons on diets with intact protein containing naturally occurring minerals and vitamins ${ }^{13}$ because previous reports have shown that when elemental medical foods are the primary source of protein equivalent, requirements to maintain biochemical indices of nutrition status within reference ranges are greater than RDAs. $^{2-5}$ The percentages of means of 3-day diets with nutrient intakes $<100 \%$ of RDIs were calculated.

\section{Whole blood and serum measures}

Venous blood was drawn $(4.5 \mathrm{~mL}$ without anticoagulant), 2 to 4 hours postprandially at baseline and 12 months of study by a certified technologist, nurse, or physician. Hemoglobin and hematocrit were analyzed in $2 \mathrm{~mL}$ of whole blood in local laboratories by automated techniques. Reference ranges for hemoglobin and hematocrit by age and gender are given in Table $3 .{ }^{14}$

Blood $(2.5 \mathrm{~mL})$ was centrifuged at $1000 \mathrm{rpm}$ for 10 minutes and serum was transferred into two $1-\mathrm{mL}$ tubes, labeled, and stored at $-70^{\circ} \mathrm{C}$, until shipment on dry ice to Clinical Nutrition Laboratory, Albuquerque, NM. Serum was used to quantitate concentrations of ferritin (enzyme immunoassay, Ferrizyme Kit, Abbott Laboratories, North Chicago, IL). Serum was also used to assay TFRs based on the double antibody sandwich method (Ramco Laboratories, Inc., Houston, TX). The concentration of TFR in the sample was determined by comparing the sample's optical density reading with a standard curve graph. ${ }^{15,16}$ Control sera of known TFR concentrations were run with each assay. All assays were run in the Clinical Nutrition Laboratory, Albuquerque, NM. According to Olivares et al., ${ }^{17}$ the sensitivity of TFR when $>135 \mu \mathrm{g} / \mathrm{L}$ is $23.6 \%$, and the specificity is $98.3 \%$. The sensitivity of TFR/ferritin ratio when $>975$ is $68.4 \%$, and the specificity is $63.3 \%$. Serum ferritin concentrations $<12 \mu \mathrm{g} / \mathrm{L}$, TFRs $\geq 9000 \mu \mathrm{g} / \mathrm{L}$, and a $\mathrm{TFR} /$ ferritin ratio $\geq 500$ were considered to be indicative of iron deficiency. ${ }^{18,19}$

\section{Statistical methods}

Nutrient intakes at baseline and during study and iron status indices at baseline and 12 months were analyzed by ANOVA. Number and percentages of hemoglobin, hematocrit, ferritin,

Table 2

Recommended dietary intakes for iron and vitamin $\mathrm{C}$ by age

\begin{tabular}{lcccc}
\hline & \multicolumn{4}{c}{ Age, yrs } \\
\cline { 2 - 5 } Nutrient & $2<4$ & $4<7$ & $7<11$ & $11<13$ \\
\hline Iron, mg & 15 & 10 & 10 & 18 \\
Vitamin C, mg & 45 & 45 & 45 & 60 \\
\hline
\end{tabular}


Table 3

Reference ranges for hemoglobin and hematocrit by age

\begin{tabular}{lcc}
\hline Age & Hemoglobin, g/dL & Hematocrit, \% \\
\hline $2<6$ yrs & $11.0-15.0$ & $33-44$ \\
$6<12$ yrs & $11.5-15.5$ & $35-45$ \\
$12<13$ yrs, F & $12.0-16.0$ & $36-46$ \\
$12<13$ yrs, M & $13.0-16.0$ & $37-49$ \\
\hline
\end{tabular}

TFRs, and transferrin receptor/ferritin ratios outside of reference ranges were calculated. A $t$ test was run to determine if there were significant differences in means of iron status indices of children $2<6$ years of age and those $6<13$ years of age. Pearson and Spearman correlation coefficients were run between iron intakes and indices of iron status. A value of $P<$ 0.05 was considered significant.

\section{RESULTS}

\section{Subjects}

Nine children were in Group I (Periflex-fed), 16 children were in Group II (Phenex-fed), and 15 children were in Group III (Phenyl-Free-fed); 1 child in each group was a protocol failure. Only children completing the study were evaluated for this report. Ages (mean \pm SEM) at study entrance were $5.8 \pm$ 0.9 years, $4.4 \pm 0.8$ years, and $7.2 \pm 0.5$ years, respectively, for Groups I, II, and III. Forty-three percent of children were female and $73 \%$ were Caucasian. Five children had consumed Periflex for $0.80 \pm 0.30$ years, 12 children had ingested Phenex for $0.86 \pm 0.28$ years, and 14 children had ingested Phenyl-Free for $3.62 \pm 0.80$ years before study entrance.

\section{Medical food and selected nutrient intakes}

Both Group I and Group III children consumed significantly greater $(P<0.001)$ amounts of medical food than Group II children (Table 4). Group III children had a greater mean intake of protein than Group I children both at baseline $(P<0.01)$ and during study. However, intake of protein as a percentage of RDI did not differ among groups. Children in Group I had seven diet diaries, children in Group II had one diet diary, and children in Group III had three diet diaries below RDI for protein during study. Group III children had a greater intake of iron than the other two groups of children as total per day and as a percentage of RDI at baseline and during study $(P<0.001)$. Only one child in Group II had two diet diaries with iron less than RDI. Table 4 describes percentages of 3 -day mean intakes of protein and iron that were $<100 \%$ of RDIs by each group. Mean vitamin C intakes of all 3 groups were significantly greater than RDIs.

\section{Iron status indices}

Table 5 provides means ( \pm SEM) of hemoglobin, hematocrit, ferritin, TFRs, and TFR/ferritin ratios at baseline and study end. Mean TFRs were significantly greater $(P<0.05)$ in
Group III children than in Group II children at baseline. At study end, no significant difference was found in any index of iron status, although mean serum ferritin tended to be lower in Group I children than in the other two groups. At baseline, eight children had TFRs $\geq 9000 \mu \mathrm{g} / \mathrm{L}$, suggesting iron deficiency. Two children were in Group I, one was in Group II, and five were in Group III,. At study end, four children ranging in age from 7.00 to 11.33 years had TFRs $\geq 9000 \mu \mathrm{g} / \mathrm{L}$, three of whom had been elevated at baseline. No significant difference was found in iron status indices of younger versus older children.

\section{DISCUSSION}

\section{Medical food and selected nutrient intakes}

Group II children had a lower mean intake of medical food than the other two groups. This lower intake of medical food was related to the greater protein equivalent content of the medical food used by Group II ( $30 \mathrm{~g} / 100 \mathrm{~g})$ compared to that of the other 2 medical foods ( $\approx 20 \mathrm{~g} / 100 \mathrm{~g}$ each). The younger age of Group II children may also have been partially responsible for the differences in intake.

The greater total daily mean protein intake during study by the children in Group III was due to the significantly older age of this group, because there were no differences between groups when mean protein intakes were presented as a percentage of RDI. Although Group II and III children consumed similar mean percentages of RDI for protein, Group I children tended to have a lower mean protein intake during study. Also, 7 of 32 3-day diet diaries of children in Group I and 3 of 56 3-day diet diaries of children in Group III failed to provide $100 \%$ of RDI for protein. Total daily mean iron intake and intake as a percentage of RDI were greatest by the children in Group III, the oldest group.

\section{Iron status indices}

A number of reports have suggested that iron deficiency and iron-deficiency anemia are common in children undergoing therapy for PKU. ${ }^{2-5,20-23}$ In the present study, after at least 1 year of ingesting study medical foods, mean indices of iron status of children in each group did not differ and were within reference ranges. However, overall, Group II children tended to have fewer indices of iron status outside the reference ranges at study end versus indices for Groups I and III. No child in any feeding group was anemic, substantiating data by Gropper et al. ${ }^{23}$

Body iron is found in three compartments. Metabolically active iron in iron-requiring proteins and enzymes is termed the functional compartment. The largest component of this compartment is hemoglobin. Iron absorbed from the gut in excess of that required for the functional compartment is incorporated into storage proteins constituting the storage compartment, of which ferritin is the major storage tissue. Storage and functional compartments are linked by a small transport compartment consisting of transferrin iron, which is delivered to tissues via TFRs on individual cells. ${ }^{18}$ Not only does the TFR 
Table 4

Mean $( \pm$ SEM $)$ daily medical food and selected nutrient intakes by children by group

\begin{tabular}{|c|c|c|c|c|}
\hline \multirow[b]{2}{*}{ Variable } & \multicolumn{3}{|c|}{ Group } & \multirow[b]{2}{*}{$P$ Value } \\
\hline & $\mathrm{I}^{a}$ & $\mathrm{II}^{b}$ & III $^{c}$ & \\
\hline No of Children & 8 & 15 & 14 & \\
\hline \multicolumn{5}{|l|}{ Medical Food } \\
\hline Baseline, $g$ & $137 \pm 13$ & $121 \pm 7$ & $180 \pm 11$ & $\mathrm{III}>\mathrm{II}, \mathrm{I},<0.001$ \\
\hline During study ${ }^{d}, \mathrm{~g}$ & $169 \pm 11$ & $124 \pm 7$ & $201 \pm 12$ & III, I $>$ II, $<0.001$ \\
\hline \multicolumn{5}{|l|}{ Protein } \\
\hline Baseline, $\mathrm{g}$ & $38.2 \pm 3.1$ & $42.9 \pm 2.0$ & $49.0 \pm 2.4$ & $\mathrm{III}>\mathrm{I},<0.01$ \\
\hline$\% \mathrm{RDI}^{e}$ & $111 \pm 8$ & $131 \pm 5$ & $132 \pm 6$ & NS \\
\hline No $(\%)^{f}<100 \%$ RDI & $3(38)$ & $0(0)$ & $4(27)$ & \\
\hline During study ${ }^{d}, \mathrm{~g}$ & $42.3 \pm 2.8$ & $46.5 \pm 1.8$ & $52.5 \pm 2.7$ & III $>$ I, 0.05 \\
\hline$\% \mathrm{RDI}^{e}$ & $115 \pm 5$ & $137 \pm 5$ & $135 \pm 6$ & NS \\
\hline No $(\%)^{f}<100 \%$ RDI & $7(22)$ & $1(2)$ & $3(5)$ & \\
\hline \multicolumn{5}{|l|}{ Iron } \\
\hline Baseline, mg & $20.3 \pm 1.5$ & $19.8 \pm 1.0$ & $28.1 \pm 1.5$ & $\mathrm{III}>\mathrm{I}, \mathrm{II},<0.001$ \\
\hline$\% \mathrm{RDI}^{e}$ & $188 \pm 20$ & $158 \pm 15$ & $263 \pm 16$ & $\mathrm{III}>\mathrm{I}, \mathrm{II},<0.001$ \\
\hline No $(\%)^{f}<100 \%$ RDI & $1(13)$ & $1(6)$ & $0(0)$ & \\
\hline During study ${ }^{d}, \mathrm{mg}$ & $23.8 \pm 1.6$ & $20.2 \pm 0.8$ & $29.7 \pm 1.6$ & $\mathrm{III}>\mathrm{I}, \mathrm{II},<0.001$ \\
\hline$\% \mathrm{RDI}^{e}$ & $209 \pm 19$ & $164 \pm 12$ & $286 \pm 17$ & III $>$ I,II, $<0.001$ \\
\hline No $(\%)^{f}<100 \%$ RDI & $0(0)$ & $2(3)$ & $0(0)$ & \\
\hline \multicolumn{5}{|l|}{ Vitamin C } \\
\hline Baseline, mg & $172 \pm 40$ & $136 \pm 11$ & $155 \pm 9$ & NS \\
\hline$\% \mathrm{RDI}^{e}$ & $382 \pm 90$ & $301 \pm 25$ & $335 \pm 18$ & NS \\
\hline During study ${ }^{d}, \mathrm{mg}$ & $153 \pm 27$ & $142 \pm 12$ & $178 \pm 14$ & NS \\
\hline$\% \mathrm{RDI}^{e}$ & $330 \pm 60$ & $312 \pm 26$ & $389 \pm 30$ & NS \\
\hline
\end{tabular}

${ }^{a}$ Periflex fed.

${ }^{b}$ Phenex fed.

${ }^{c}$ Phenyl-Free fed.

${ }^{d}$ During Study represents data from all 4 postbaseline visits.

${ }^{e}$ Percentage of means of 3-day diet diaries; during study, Group I children submitted 32 3-day diet diaries, Group II children submitted 60 3-day diet diaries, and Group III children submitted 563 -day diet diaries.

${ }^{f}$ Number and percent of 3-day diet diaries.

NS, No significant differences.

facilitate the transport of transferrin-bound iron from the extracellular environment to the intracellular endocytic vesicle, but it also impedes the release of iron from transferrin at the cell surface and, thus, protects the membrane from peroxidative injury. ${ }^{19}$ The present study is the first to evaluate iron status of children with PKU by evaluating serum TFR concentrations.

According to Anttila et al., ${ }^{24}$ serum TFR concentrations $\geq 9000 \mu \mathrm{g} / \mathrm{L}$ and serum ferritin concentrations $<12 \mu \mathrm{g} / \mathrm{L}$ indicate iron deficiency. Storage iron is assayed by measuring serum ferritin concentrations that are elevated by inflammation and chronic disease, ${ }^{18}$ whereas the transport compartment iron, not influenced by inflammation, is assayed by measuring serum TFR concentrations. TFR/ferritin ratios $\geq 500$ are also indicative of iron deficiency. ${ }^{18} \mathrm{In}$ this study, when TFR and TFR/ferritin ratios were used to determine iron deficiency, at study end, children in Groups I and III had the highest number of these indices above reference ranges despite the fact that no child in either group reportedly had a low iron intake. Although children in Groups I and III were older than Group II children and were expected to have lower mean TFR concentrations, they tended to have higher mean concentrations, suggestive of iron deficiency. According to Antilla et al., ${ }^{24}$ body iron stores decreased in boys (13.7 \pm 0.05 years of age, mean \pm SEM at study end) during pubertal development, demonstrated by a decrease in serum ferritin and an increase in TFR concentrations. One male in each group in the present study was $>10$ years of age at study end (Group I, 11.67 
Table 5

Hemoglobin, hematocrit, ferritin, transferrin receptors, and transferrin receptor/ferritin ratios: Mean ( \pm SEM) and percent outside reference ranges in children at baseline and study end by group

\begin{tabular}{|c|c|c|c|}
\hline \multirow[b]{2}{*}{ Variable } & \multicolumn{3}{|c|}{ Group } \\
\hline & $\mathrm{I}^{a}$ & $\mathrm{II}^{b}$ & $\mathrm{III}^{c}$ \\
\hline No. of Children & 8 & 15 & 14 \\
\hline \multicolumn{4}{|c|}{ Hemoglobin, g/dL } \\
\hline Baseline & $12.3 \pm 0.2$ & $12.8 \pm 0.2$ & $12.9 \pm 0.2$ \\
\hline Study end & $12.7 \pm 0.3$ & $12.9 \pm 0.2$ & $12.9 \pm 0.2$ \\
\hline \multicolumn{4}{|l|}{ Hematocrit, \% } \\
\hline Baseline & $35.5 \pm 0.4$ & $37.0 \pm 0.6$ & $37.4 \pm 0.5$ \\
\hline Study end & $36.4 \pm 1.0$ & $37.5 \pm 0.5$ & $37.0 \pm 0.6$ \\
\hline \multicolumn{4}{|c|}{ No (\%) below reference range } \\
\hline Baseline & $1(13)$ & $1(7)$ & $0(0)$ \\
\hline Study end & $2(25)$ & $0(0)$ & $1(7)$ \\
\hline \multicolumn{4}{|l|}{ Ferritin, $\mu \mathrm{g} / \mathrm{L}$} \\
\hline Baseline & $26 \pm 5$ & $28 \pm 3$ & $35 \pm 4$ \\
\hline Study end & $23 \pm 4$ & $31 \pm 6$ & $32 \pm 5$ \\
\hline \multicolumn{4}{|c|}{ No $(\%)$ below reference range $(<12 \mu \mathrm{g} / \mathrm{L})$} \\
\hline Baseline & $0(0)$ & $1(7)$ & $0(0)$ \\
\hline Study end & $0(0)$ & $1(7)$ & $0(0)$ \\
\hline \multicolumn{4}{|c|}{ Transferrin Receptors, $\mu \mathrm{g} / \mathrm{L}$} \\
\hline Baseline & $8100 \pm 1200$ & $6000 \pm 400$ & $8000 \pm 500^{d}$ \\
\hline Study end & $6500 \pm 600$ & $6400 \pm 600$ & $8100 \pm 800$ \\
\hline \multicolumn{4}{|c|}{ No $(\%)$ above reference range $(\geq 9000 \mu \mathrm{g} / \mathrm{L})$} \\
\hline Baseline & $2(25)$ & $1(7)$ & $5(36)$ \\
\hline Study end & $1(13)$ & $1(7)$ & $2(14)$ \\
\hline \multicolumn{4}{|c|}{ Transferrin Receptor/Ferritin Ratio } \\
\hline Baseline & $409 \pm 125$ & $254 \pm 33$ & $308 \pm 56$ \\
\hline Study end & $337 \pm 58$ & $291 \pm 50$ & $339 \pm 65$ \\
\hline \multicolumn{4}{|c|}{ No (\%) above reference range $(\geq 500)$} \\
\hline Baseline & $1(13)$ & $0(0)$ & $3(21)$ \\
\hline Study end & $2(25)$ & $2(13)$ & $3(21)$ \\
\hline
\end{tabular}

${ }^{a}$ Periflex fed.

${ }^{b}$ Phenex fed.

${ }^{c}$ Phenyl-Free fed.

${ }^{d}$ III $>$ II, $P<0.05$.

years; Group II, 11.33 years; Group III, 12.16 years). Tanner development stage was not assessed at study end. However, because of the young age of these males, it is unlikely that pubertal development influenced iron status indices.

Overweight has been associated with iron deficiency anemia. ${ }^{25}$ In the present study, seven children were $>95$ th centile in weight (data not shown). A posthoc Pearson correlation was run between BMI z-scores and serum ferritin and transferrin receptor concentrations. No correlation was found $(P=0.33$, 0.21 , ferritin and transferrin receptor, respectively).
Although a serum ferritin of $<10 \mu \mathrm{g} / \mathrm{L}$ was used for the $3<$ 6 year old children in the Third National Health and Nutrition Examination Survey and 3\% had iron deficiency, none of 153 $<6$-year-old children in the present study had a serum ferritin $<10 \mu \mathrm{g} / \mathrm{L}$ and only 1 had a serum ferritin $<12 \mu \mathrm{g} / \mathrm{L}$. Of the 21 children in the present study in the $6<13$-year-old range at study end, four had two indices of iron deficiency, a percentage with iron deficiency greater than found in this age group in the Third National Health and Nutrition Examination Nutrition Survey $(1988-1994) .26$ 
Reasons for iron status indices suggestive of iron deficiency in a few children in view of reported excellent iron intakes could be multiple. First and foremost is the possibility that parents recorded all prescribed medical food, the primary iron source, as consumed when it was not. The child with a ferritin concentration $<12 \mu \mathrm{g} / \mathrm{L}$ at baseline and study end failed to consume all medical food prescribed. Although inadequate reporting of medical food intake may have occurred in the present study, iron deficiency occurred in a small subsample of infants with PKU where recording of diet diaries was likely correct. ${ }^{3,27}$ Poor absorption of iron from diets containing only nonheme iron is another possible cause of iron deficiency. Alexander et al. ${ }^{28}$ reported negative iron balance in children ingesting amino acid mixes or casein hydrolysate containing nonheme iron. Ascorbic acid improves nonheme iron absorption $^{29}$ and children in this study had intakes of vitamin C that did not differ and mean intakes were $>300 \%$ of RDI. Thus, vitamin C deficiency was not responsible for poor iron status. Frequent blood draws could also result in iron deficiency but were the same for the 3 groups of children. Alteration of iron metabolism in children with phenylketonuria may occur.

Serotransferrins normally contain two to three tyrosyl groups that are involved in the binding of iron. ${ }^{30}$ Substitution of one amino acid for another in human transferrins has been observed and may directly affect the binding of iron or may affect protein conformation and thus indirectly affect the binding of iron..$^{30}$ Other metabolic reasons not yet explored may be responsible for iron deficiency and require study in a large group of children. Whatever the reasons for iron deficiency in children with PKU, we suggest that the clinical management of both infants and children include routine evaluation of iron status indices beginning at 6 months of age. Transferrin receptor and ferritin concentrations should be obtained in order that ratios may be calculated. Prevention or early treatment of iron deficiency may improve cognitive development and behavior of children with PKU. ${ }^{9-11}$

\section{Conclusions}

Of 37 children with PKU undergoing nutrition management, 7 had an elevated TFR/ferritin ratio, 4 had elevated transferrin receptors, and 1 had a low ferritin at the end of a 1 -year study. No child had a hemoglobin concentration indicative of anemia. Reasons for iron deficiency are unclear and may be multiple. However, early and frequent evaluation of iron status by assessing transferrin receptors, ferritin, and TFR/ ferritin ratios leading to iron therapy where deficiency is found may improve cognitive and behavioral outcomes of children with PKU.

\section{ACKNOWLEDGMENTS}

Mary Jane Kennedy, RN, at Emory University School of Medicine, Atlanta, GA, is gratefully acknowledged for help with recruitment.

\section{References}

1. Scriver CR, Kaufman S. Hyperphenylalaninemia: Phenylalanine hydroxylase deficiency. In: Scriver CR, Beaudet AL, Sly WS, et al, editors. The Metabolic and Molecular Bases of Inherited Disease. New York: McGraw-Hill, Inc., 2001:1667-1724.

2. Gropper SS, Acosta PB, Clarke-Sheehan N, Wenz E, Cheng M, Koch R. Trace element status of children with PKU and normal children. J Am Diet Assoc 1988;88: $459-465$.

3. Acosta PB, Greene C, Yannicelli S, Korson M, Rohr F, Hooper L et al. Nutrition studies in treated infants with phenylketonuria. Int Pediatr 1993;8:6-16.

4. Bodley JL, Austin VJ, Hanley WB, Clarke JTR, Zlotkin S. Low iron stores in infants and children with treated phenylketonuria: A population at risk for iron-deficient anaemia and associated cognitive deficits. Eur J Pediatr 1993;152:140-143.

5. Scaglioni S, Zuccotti G, Vedovello M, Rottoli A, Paccanelli S, Longhi R et al. Study of serum ferritin in 58 children with classic phenylketonuria and persistent hyperphenylalaninaemia. J Inherit Metab Dis 1985;8:160.

6. Food and Nutrition Board Committee on Nutrition. Recommended Dietary Allowances, 9th ed. Washington, DC: National Academy of Sciences, 1980.

7. Food and Nutrition Board Committee on Nutrition. Recommended Dietary Allowances, 10th ed. Washington, DC: National Academy of Sciences, 1989.

8. Layrisse M, Garcia-Casal MN, Solano L, Baron MA, Arguello F, Llovera D et al. Iron bioavailability in humans from breakfasts enriched with iron bis-glycine chelate, phytates and polyphenols. J Nutr 2000;130:2195-2199.

9. Walter T. Impact of iron deficiency on cognition in infancy and childhood. Eur J Clin Nutr 1993;47:307-316.

10. Lozoff B. Behavioral alterations in iron deficiency. Adv Pediatr 1988;35:331-359.

11. Scriver CR, Kaufman S. The hyperphenylalaninemias. In: Scriver CR, Beaudet AL, Sly WS, Valle D, editors. The Metabolic and Molecular Bases of Inherited Disease. New York: McGraw-Hill, Inc., 2001:1667-1724.

12. Tanner JM. Growth at Adolescence, 2nd ed. Oxford, UK: Blackwell Scientific Pub lications, 1962.

13. Trumbo P, Schlicker S, Yates AA, Poos M. Dietary reference intakes for energy, carbohydrate, fiber, fat, fatty acids, cholesterol, protein and amino acids. J Am Diet Assoc 2002;102:1621-1630.

14. Behrman RE, Kleigman RM, Arvin AM, editors. Textbook of Pediatrics, 15 ed. Philadelphia: WB Saunders, Co, 1996.

15. Flowers CH, Skikne BS, Covell AM, Cook JD. The clinical measurement of serum transferrin receptor. J Lab Clin Med 1989;114:368-377.

16. Virtanen MA, Viinikka LU, Virtanen MK, Svahn JC, Anttila RM, Krusius T et al. Higher concentrations of serum transferrin receptor in children than in adults. Am J Clin Nutr 1999;69:256-260.

17. Olivares M, Walter T, Cook JD, Hertrampf E, Pizarro F. Usefulness of serum transferrin receptor and serum ferritin in diagnosis of iron deficiency in infancy. Am J Clin Nutr 2000;72:1191-1195.

18. Baynes RD. Refining the assessment of body iron status. Am J Clin Nutr 1996;64: 793-794.

19. Baynes RD, Skikne BS, Cook JD. Circulating transferrin receptors and assessment of iron status. J Nutr Biochem 1994;5:322-330.

20. Acosta PB, Stepnick-Gropper S, Clarke-Sheehan N, Wenz E, Cheng M, Anderson K, Koch R. Trace element status of PKU children ingesting an elemental diet. JParenter Enteral Nutr 1987;11:287-292.

21. Böhles H, Ullrich K, Endres W, Behbehani AW, Wendel U. Inadequate iron availability as a possible cause of low serum concentrations in patients with phenylketonuria. Eur J Pediatr 1991;50:425-428.

22. Miranda da Cruz BDO, Seidler H, Widhalm K. Iron status and iron supplementation in children with classical phenylketonuria. J Am Coll Nutr 1993;12:531-536.

23. Gropper SS, Trahms C, Cloud HH, et al. Iron deficiency without anemia in children with phenylketonuria. Int Pediatr 1994;9:237-243.

24. Antilla R, Cook JD, Siimes MA. Body iron stores decrease in boys during pubertal development: The transferrin receptor-ferritin ratio as an indicator of iron status. Pediatr Res 1997;41:224-228.

25. Bonuck KA, Kahn R. Prolonged bottle use and its association with iron deficiency anemia and overweight: a preliminary study. Clin Pediatr (Phila) 2002;41:603-607.

26. Looker AC, Dallman PR, Carroll MD, Gunter EW, Johnson CL. Prevalence of iron deficiency in the United States. JAMA 1997;277:973-976.

27. Acosta PB, Yannicelli S. Plasma micronutrient concentrations in infants undergoing therapy for phenylketonuria. Biol Trace Elem Res 1999;67:75-84.

28. Alexander FW, Clayton BE, Delves HT. Mineral and trace-metal balances in chil dren receiving normal and synthetic diets. Q J Med 1974;169:89-111.

29. Hunt JR, Mullen LM, Lykken GI, Gallagher SK, Nielsen FH. Ascorbic acid: effect on ongoing iron absorption and status in iron-depleted young women. Am J Clin Nutr 1990;51:649-655.

30. Bezkorovainy A. Biochemistry of Nonheme Iron. New York: Plenum Press, 1980. 